\title{
Article \\ Cydalima perspectalis in Poland-8 Years of Invasion against the Background of Three Other Invasive Species
}

\author{
Paweł K. Bereś $\left.{ }^{1}{ }^{(}\right)$, Patrycja Ziętara ${ }^{2}$, Mirosław Nakonieczny ${ }^{2, *} \mathbb{C}$, tukasz Kontowski ${ }^{3}$, Michał Grzbiela ${ }^{4}$ \\ and Maria Augustyniak ${ }^{2} \mathbb{C}$ \\ 1 Regional Experimental Station in Rzeszów, Institute of Plant Protection-NRI, ul. Langiewicza 28, \\ 35-101 Rzeszów, Poland; p.beres@iorpib.poznan.pl \\ 2 Institute of Biology, Biotechnology and Environmental Protection, Faculty of Natural Sciences, \\ University of Silesia in Katowice, ul. Bankowa 9, 40-007 Katowice, Poland; patrycja.zietara@us.edu.pl (P.Z.); \\ maria.augustyniak@us.edu.pl (M.A.) \\ 3 Agricultural Holding in Szałkowo, ul. Szałkowo 36A, 14-200 Iława, Poland; lukaszkont@wp.pl \\ 4 United Phosphorus Limited, ul. Stawki 40, 01-040 Warszawa, Poland; michal.grzbiela@onet.eu \\ * Correspondence: miroslaw.nakonieczny@us.edu.pl; Tel.: +48-600-377-027
}

Citation: Bereś, P.K.; Ziętara, P.; Nakonieczny, M.; Kontowski, Ł.; Grzbiela, M.; Augustyniak, M. Cydalima perspectalis in Poland-8 Years of Invasion against the Background of Three Other Invasive Species. Diversity 2022, 14, 22. https://doi.org/10.3390/d14010022

Academic Editor: Luc Legal

Received: 24 November 2021 Accepted: 23 December 2021 Published: 31 December 2021

Publisher's Note: MDPI stays neutral with regard to jurisdictional claims in published maps and institutional affiliations.

Copyright: (C) 2021 by the authors. Licensee MDPI, Basel, Switzerland. This article is an open access article distributed under the terms and conditions of the Creative Commons Attribution (CC BY) license (https:// creativecommons.org/licenses/by/ $4.0 /)$.

\begin{abstract}
The box tree moth (Cydalima perspectalis) origins from East Asia. In Europe, it was recorded for the first time in 2007, and in Poland in 2012. By the end of 2020, it was found all over Poland. There are no published data on the range of $C$. perspectalis occurrence in Poland because it is not a quarantine pest in the European Union and is not subject to official monitoring. Data collected in 2018-2020 via a website dedicated to monitoring, for the first time, illustrate the current range and its largest concentrations in southern and central Poland. The monitoring confirmed that the main directions of the invasion are related to the main communication routes of Poland (south-north) and are of a long-distance character. The dispersal pattern corresponds to the model developed for Cameraria ohridella: a stratified dispersal model that considers long-distance road/rail transport. The second important factor contributing to the invasion of $C$. perspectalis are large human communities enabling rapid local dispersion (a diffusion model). Comparing its invasion with the monitoring data from 2007-2013 of two other invasive pests of Poland: Ostrinia nubilalis and Diabrotica virgifera, shows that a diffusion model best describes the spatial spread of these pests only to uninhabited neighboring areas.
\end{abstract}

Keywords: Poland; Europe; Cydalima perspectalis; box tree moth; invasive species

\section{Introduction}

The natural range of the box tree moth (Cydalima perspectalis Walker, 1859) is in Southeast Asia's humid subtropical regions. Described in the mid-nineteenth century from China, it was found in India half a century later. At the turn of the 20th and 21st centuries, its presence was confirmed in Korea, Japan, and Russia's the Far East [1-3]. C. perspectalis was recorded in Europe for the first time in 2007 in Germany (Baden-Württemberg, the city of Weil am Rhein) and in the Netherlands. Considering the size of the damage done at the place of its first finding should be assumed that it was brought to Europe at least two years earlier. The places of dispersion to Europe are most probably the distribution centers of ornamental plants imported from China in Germany and the Netherlands [1]. Eggs and caterpillars, especially of the earlier stages, move easily along with the boxwood bushes (including cuttings) transported for commercial purposes. Molecular studies of the mitochondrial cytochrome oxidase I and II genes indicate that the source of European populations is multiple introductions of insects from eastern China due to the rapid, longdistance transport of boxwood shrubs as part of the ornamental plant trade from this country to Europe. The lack of precise legal regulations in the trade of ornamental plants, the liberalization of the existing law, and the general trade globalization facilitated such a 
rapid spread of the species to and in Europe [4]. By 2020, C. perspectalis had infested almost all of Europe (Figure 1). It is recorded from Great Britain through southern Scandinavia, Lithuania, Western Ukraine, and Russia in the east, to the Balkans and Portugal in the south [4-13]. It has also been reported in Turkey, Georgia, and Dagestan [14-16]. The current range of occurrence of this species in Europe is consistent with the bioclimatic model (CLIMEX ${ }^{\circledR}$ ) prepared in 2014 for C. perspectalis, in which its potential range was established based on the lower development threshold temperature, which depends on latitude and altitude (up to $2000 \mathrm{~m}$ above sea level in Georgia). The range of C. perspectalis in the north is limited by the low temperature, which prevents the closure of one life cycle per year. In the south, by the requirements related to obligatory diapause [5].
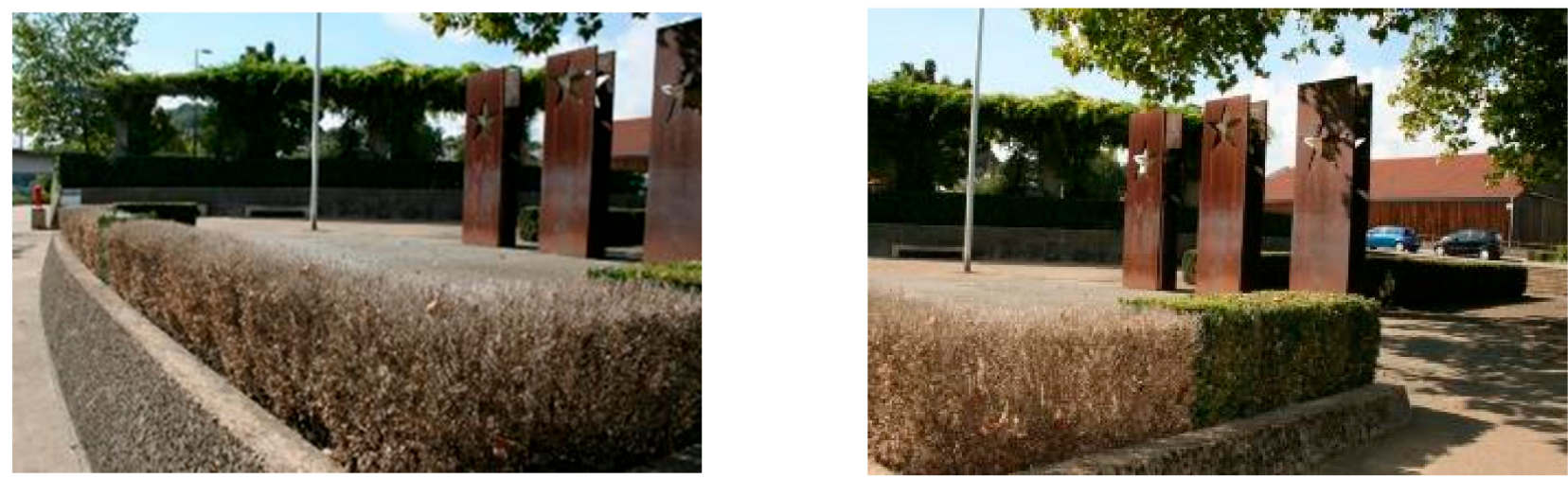

Figure 1. "Twist of fate" - a boxwood hedge in front of the European Museum in Schengen, damaged by an East Asian invasive box tree moth (September 2019). Photo: M. Nakonieczny.

The biology of the species in Poland has not been fully described yet. In Europe, C. perspectalis can develop up to five generations a year depending on the latitude. The main factor limiting its development is temperature, as the lower developmental threshold for the immature stages is $8-12{ }^{\circ} \mathrm{C}$. However, it is known that it has a variable number of generations during the year, depending on weather (mean temperature) conditions too. The female lays gelatinous, transparent eggs with up to 20 in the batches. A maximum of a female can lay up to 500 eggs [3,17]. Depending on the temperature, 2-3 mm long larvae hatch from the eggs after a few to several days. Then, 3-4 weeks later, they reach their maturity size of about $4 \mathrm{~cm}$. At a temperature of $20^{\circ} \mathrm{C}$, the development from hatching to the adult takes about 40 days [5,17]. At $25{ }^{\circ} \mathrm{C}$, the average duration of each larval stage is three days, with an extended photoperiod shortening the development time of the larvae [18]. The pre-pupa stage lasts approximately eight days. At $25^{\circ} \mathrm{C}$, the imago appears after about ten days. The adult insect lives up to two weeks. In autumn, when the temperature drops, the caterpillars build cocoons from the leaves and hibernate $[5,17,19]$. In Central Europe, where there are usually two generations, the insect needs 518 degree days for the over wintering generation, and 430 for the second generation to complete the cycle. This difference translates into a different mean growth rate, higher in the first generation of insects feeding in spring than in larvae feeding in autumn [17].

Hatching larvae feed as a group first and then disperse. The foraging during the boxwood growing season varies spatially. In spring, most of the larvae feed in the lower parts of the shrubs. In summer, they feed on the middle parts, and in autumn, they feed on leaves in the top part, which causes of plant death [20]. Last instar larvae, in the leaves absence, may feed on the shoots by gnawing out phloem. Foraging is accompanied by the formation of filaments that form dense, hydrophobic clusters of leaves, which facilitates the identification of attacked plants, but makes it difficult to control the larvae, both by chemical and biological methods. The pupa is tied in a cocoon of leaves entwined with yarn, protecting it against low temperatures and pesticides $[17,19]$. In Central Europe, the insect undergoes obligatory diapause in winter, lasting at least eight weeks. The larva of the 
3rd stage of the second generation of insects usually hibernates $[5,18]$. It forms leaf cocoons, usually inside the bush, making it difficult to assess the degree of plant infestation and making it easier to withstand frosts. Over wintering caterpillars can survive a temperature drop-down to $-30{ }^{\circ} \mathrm{C}$, which is not uncommon in north-eastern Poland. Shortening of the photoperiod and the growing food shortage caused by the intensive feeding of the larvae of both generations, exceeding the regenerative capacity of the host plant, may cause diapause as well $[3,18]$.

Recently, Suppo and his team [21] introduced the first phenology model for the box tree moth based on a temperature and photoperiod to simulate the life cycle of this insect and the developmental rate for each life stage. Minimum temperature appeared the most critical parameter for the model, while diapause was negligible. The model shows that higher temperatures associated with global warming can significantly increase the number of pest generations during the year and may lead to the overlapping of successive generations and the over wintering of caterpillars at various instars [21]. Results obtained by Poitou et al. [22] confirmed the positive effect of increasing temperature on the rate and dynamics of diapause termination and lack of stimulatory effect of photoperiod. The recent models of C. perspectalis spreading in Catalonia showed the importance of its host plant presence, dispersal capacity, and climate suitability [23].

On the map of the range of the box tree moth in Europe from 2012, prepared by a team of researchers from CABI-Switzerland [24], Poland was noted as a country where this species does not appear yet. The first information (published in Polish) about $C$. perspectalis in Poland comes from the village of Michałkowa in the Sowie Mountains (southwestern Poland, Lower Silesia), where the insect was detected in 2012 [25]. The following data on the places where the pest appeared come from 2015. This year, Blaik et al. [25] detected C. perspectalis in Suchy Bór near Opole (Opole voivodeship) and in the downtown Kraków (Lesser Poland), which indicates that the pest infested the southern part of the country. Further confirmed information on the range of $C$. perspectalis in Poland comes from southeastern Poland (Subcarpathian voivodeship). In the years 2016-2017, insects' presence was detected in the following towns: Grabiny, Rzeszów, Umieszcz, and Zgłobień [26]. This expansion clearly indicated the latitudinal direction of the insect spread in Poland, parallel to the Carpathian arc until the 2017 year.

An example of a quick and destructive boxwood moth invasion is the Botanical Garden in Łódź (central Poland). The first signs of foraging were found in the autumn of 2018, while in June 2021, the last, utterly dead boxwood hedges were removed. The garden does not currently have any boxwood collection (Figure 2a-c).

An important document that authorized us to undertake monitoring activities is the "Proposal for a resolution of the European Parliament on the boxwood moth (Cydalima perspectalis)", which encourages the Commission to:

- Recognize the box tree moth as a harmful organism under Directive 2000/29/E.C.;

- Support research into biological controls for the box tree moth through existing funding programs;

- Promote joint monitoring of the box tree moth by the competent European authorities [27].

The recognition by the EU of the need to monitor the boxwood moth in Europe indicates that the importance of this species is very high and noticeable in individual countries where $C$. perspectalis can pose a severe threat to boxwood hedges and topiaries as well as wild plants. 


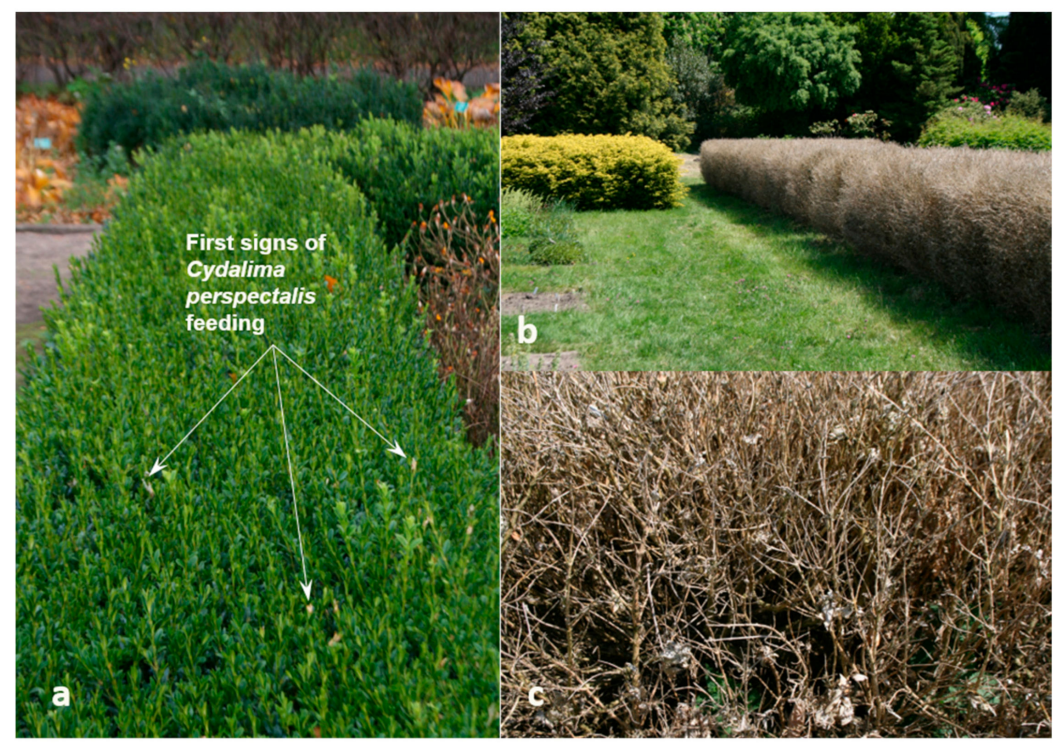

Figure 2. About a 50-year-old boxwood hedge damaged by C. perspectalis in the Botanical Garden in Łódź (Central Poland): (a) traces of feeding found one year after the first box tree moth was noticed in the garden despite the use of an insecticide (Łódź, October 2019); (b) wholly defoliated hedge in the Botanical Garden in Łódź in June 2021; (c) dead boxwood shoots without bark (June 2021). Photo $(\mathbf{a}-\mathbf{c})$ : M. Nakonieczny.

In the last 30 years, the invasion of many insect species, alien to the Polish entomofauna, have been found in Poland [28]. However, some of them were particularly spectacular and of real economic importance. These include the invasions of Ostrinia nubilalis (European corn borer), Diabrotica virgifera virgifera (Western corn rootworm), and Cameraria ohridella (Horse-chestnut leaf miner). There are many differences and similarities to that found for C. perspectalis in their pace and spread directions.

The study aims were to determine the current range of $C$. perspectalis occurrence in Poland, and the pace and degree of its invasiveness. Obtained data will allow a more precise definition of the threats to the cultivated boxwood, especially those of historical and cultural importance. A comparison of the invasions of the box tree moth with other invasive species in Poland from the last 20 years should enable the use of models of spatial spreading and occurrence developed for other species. Although in 2020, C. perspectalis was recorded almost all over Poland, there are no officially published data on this subject.

\section{Materials and Methods}

\subsection{Cydalima Perspectalis}

In Poland, the official monitoring of pest's occurrence conducted by the Main Inspectorate of Plant Health and Seed Inspection does not cover C. perspectalis. In the European Union, it is not a quarantine organism. For this reason, since its first finding in several locations in the southwest and southern Poland in 2012 [25,26], there is no reliable and systematic information about the directions of the spread of this species. Because box trees are cultivated all over Poland, especially Buxus sempervirens, many scenarios for this insect's spread were possible.

Because there is no system for monitoring the spread of the box tree moth in Poland, in 2018-2020, it was decided to establish its range. Since 2018, there has been a dramatic increase in the number of reports from gardeners and plant breeders in southern and central Poland about damaged box trees as a result of foraging a new, unknown boxwood pest. However, the problem was that in the national database, which is responsible for tracking the spread of various species in Poland, operating as part of the Biodiversity Map conducted by The Polish Biodiversity Information Network (PolBIN, KSIB) in 2018, only one town was listed (Warsaw) to be infested by C. perspectalis [29]. 
To identify the current range of C. perspectalis occurrence in Poland, the database of the internet website "Allotment and Garden Our Passion" [30], which brings together over 15,000 gardeners from Poland, was used. For this purpose, hobby gardeners gathered around this website provided information via social media (Facebook, Instagram) about the towns where they found the box tree moth on their plants from April 2018 to November 2020. Using the e-mail address provided on the main page of the website using the subwebsite "Contact", they provided the name of the place in their e-mail correspondence, including additional information, e.g., the date of the pest's appearance, photographs, or information (photographs) about the condition of the boxwoods. Each year, these places were verified by analyzing the photos of the damage and/or insects sent and field trips. Inspection visits were carried out annually from April to September, especially to locations from which the submitted documentation raised any doubts (Figure 3a,b). The presence of the box tree moth was verified in all voivodeships (the highest-level administrative division of Poland) from which the reports came. Particular attention was paid to the places farthest from where the box tree moth had already been found in previous reports. The resulting maps of the range of the box tree moth do not cover all the places where C. perspectalis occurs but show critical areas for subsequent reports of this insect's presence.

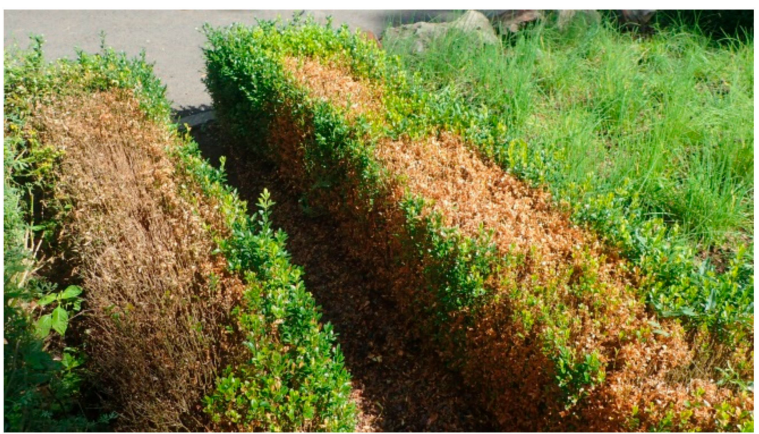

(a)

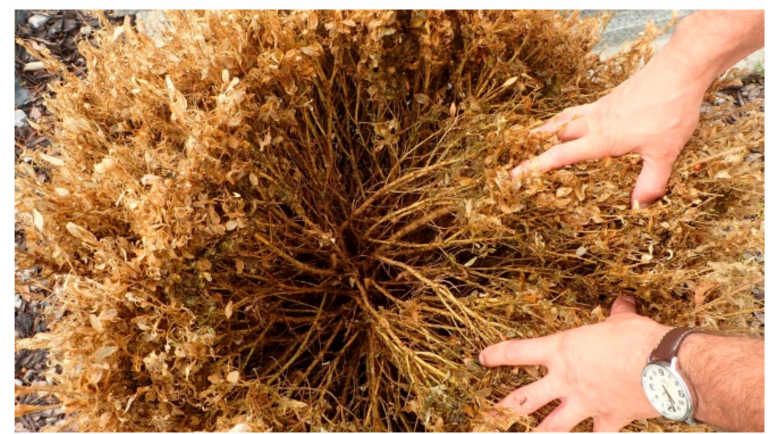

(b)

Figure 3. Buxus sempervirens bushes damaged by C. perspectalis: (a) an example of a positively verified photograph uploaded to the website "Allotment and Garden Our Passion"; (b) an example of verification of a report on the presence of C. perspectalis in the field: Trzebownisko near Rzeszów, September 2020, Photo: P. Bereś.

\subsection{Ostrinia nubilalis, Diabrotica virgifera virgifera, Cameraria ohridella (Selected Methodological Issues for Comparative Purposes)}

- Ostrinia nubilalis. In Poland, monitoring of this species was carried out by inspectors of the State Plant Health and Seed Inspection Service (SPHSIS) and the Institute of Plant Protection-National Research Institute, Regional Experimental Station in Rzeszów (IPP-NRI). The monitoring started in 2004, and was completed in 2013. As it would not be a quarantine pest, the observations made by inspectors were only used to signal the presence of the pest in the second-degree administrative division units in Poland (the first-degree are voivodships), such as counties and cities with the rights of counties (there are 380 counties in Poland). Therefore, 50 to 150 plants at the ripening dough stage $(\mathrm{BBCH} 85)$ were inspected depending on the cultivation area. On small maize crops on up to 1 ha, 50 plants were observed, while on fields of more than 1 ha, the number of plants increased to 150. Inspections were carried out at the end of August and the beginning of September. Observations were carried out based on the methodology provided in an annex to a manual for plant inspection services concerning forecasting, alerting, and data recording drawn up by SPHSIS. In all the years of the study, observations were terminated when any signs of caterpillars feeding were recorded. The county taken by $O$. nubilalis was considered any in which symptoms of caterpillars feed on at least one maize plantation. Hence, the monitoring was qualitative rather than quantitative [31,32]. 
- Diabrotica virgifera virgifera. Since it was a quarantine species subject to European monitoring, the State Plant Health and Seed Inspection Service (SPHSIS) was responsible for its monitoring in Poland. The species was first detected in Poland in 2005, and official state monitoring started in 2006 and was completed in 2013 (end of quarantine in EU). Changes in the number of D. virgifera adults were monitored with two types of trap: PTs-CSALOMON ${ }^{\circledR}$ PAL transparent sticky "cloak" trap, baited with synthetic sex pheromone (lures only males), and FTs-CSALOMON ${ }^{\circledR}$ PALs yellow sticky "cloak" trap (lures females and males). In 2006-2013, the monitoring was qualitative (finding the presence of the pest in a given crop area) and quantitative to take appropriate measures to protect maize crops and control the pest under the European Union Directives [33,34].

- Cameraria ohridella. There were no monitoring studies conducted. Information about the occurrence was often obtained from the press and popular science literature. There is no possibility of recreating the migration routes for this species in Poland, which would be determined based on monitoring or scientific research. Apart from scientific articles, the spread map of C. ohridella was prepared using the Polish Biodiversity Map database "BioMap", where scientists officially confirm the observed appearance of the pest $[35,36]$.

\section{Results}

\subsection{Cydalima Perspectalis}

In total, in 2018-2020, thanks to gardeners and plant breeders, users of the website "The Allotment and the Garden Our Passion" were collecting information from 166 places (towns) in Poland in the form of 674 documented reports on the presence of C. perspectalis in all voivodeships (Figures 4-6 and Tables S1 and S2).

Table 1. List of voivodeships and numbers assigned to them in the publication.

\begin{tabular}{cccccc}
\hline Number & Voivodeship (PL) & Voivodeship (ENG) & Number & Voivodeship (PL) & Voivodeship (ENG) \\
\hline 1 & zachodniopomorskie & West Pomeranian & 9 & dolnoślaskie & Lower Silesian \\
2 & pomorskie & Pomeranian & 10 & łódzkie & Łódź \\
3 & warmińsko-mazurskie & Warmian-Masurian & 11 & świętokrzyskie & Holy Cross \\
4 & lubuskie & Lubusz & 12 & lubelskie & Lublin \\
5 & wielkopolskie & Greater Poland & 13 & opolskie & Opole \\
6 & kujawsko-pomorskie & Kuyavian-Pomeranian & 14 & ślaskie & Silesian \\
7 & mazowieckie & Masovian & 15 & małopolskie & Lesser Poland \\
8 & podlaskie & Podlaskie & 16 & podkarpackie & Subcarpathian \\
\hline
\end{tabular}

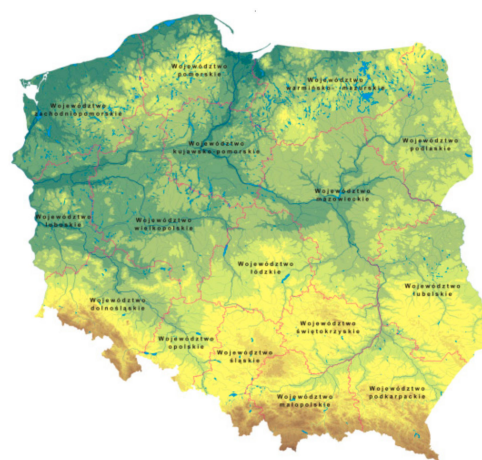

(a)

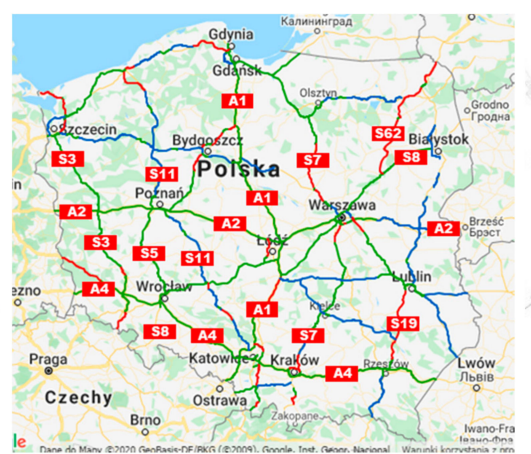

(b)

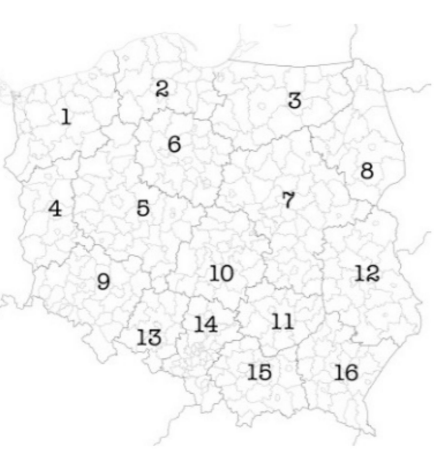

(c)

Figure 4. (a) The hypsometric and administrative map of Poland (source: https://pl.wikipedia.org/ wiki/) (accessed on 17 November 2021); (b) main road routes in Poland (source: https:/ /www.google. $\mathrm{pl} / \mathrm{maps} /$---modified) (accessed on 17 November 2021); (c) administrative division of Poland into 16 voivodeships. (names of voivodships—-see Table 1; 1-16: numbers assigned to individual voivodships). 


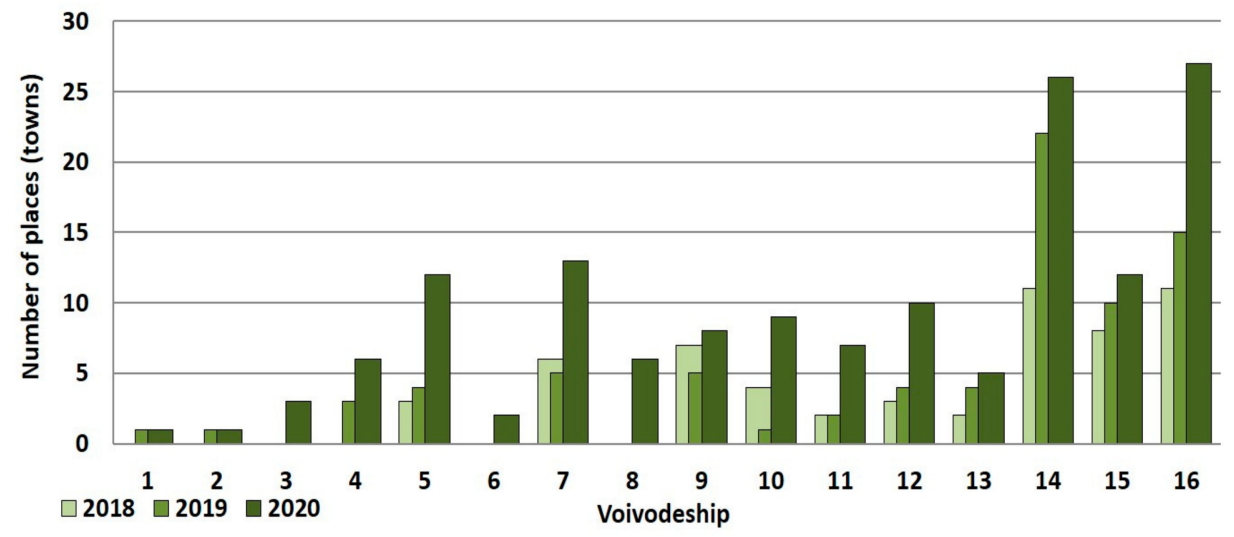

Figure 5. The number of places (towns) where Cydalima perspectalis was recorded in individual voivodships in 2018-2020. Axis X: 1-16-numbers assigned to individual voivodships; see Table 1.

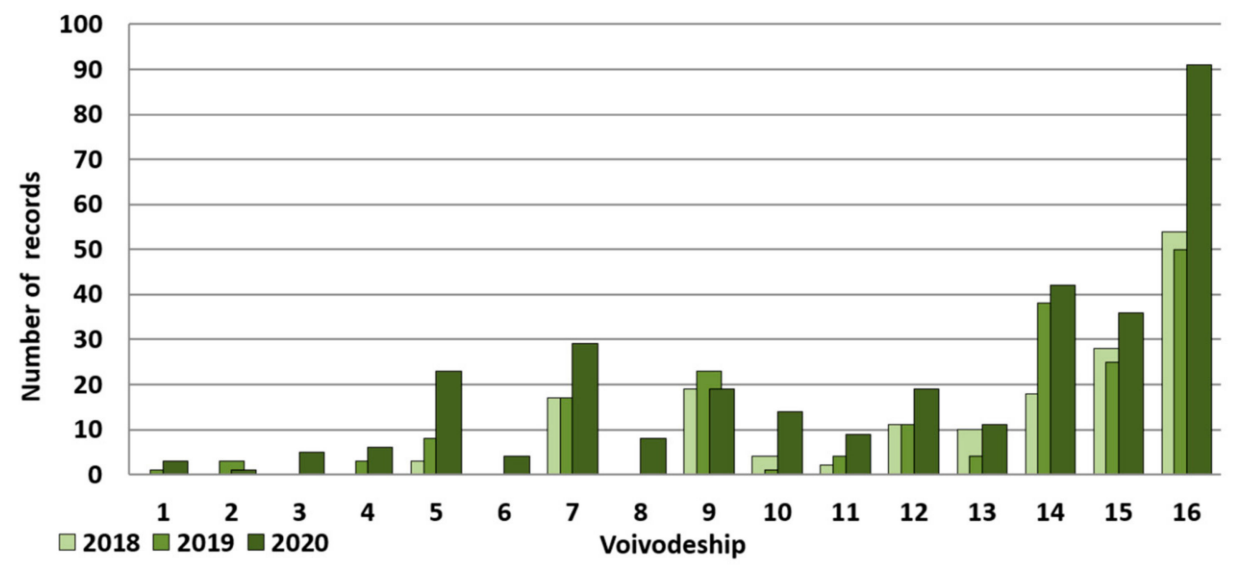

Figure 6. The number of confirmed records of Cydalima perspectalis occurrence in individual voivodeships in 2018-2020. Axis X: 1-16-numbers assigned to individual voivodships; see Table 1.

Three years of social monitoring of $C$. perspectalis in Poland allow us to conclude that there was an increase in the population size in all voivodeships each year, both in moth-controlled cities (new locations) and in the reported records. In the last 2020 year of research, we revealed the presence of box tree moths in Warmian-Masurian, KuyavianPomeranian, and Podlaskie voivodeships (No.: 3, 6, and 8). The most significant increase in the number of new locations and reported records in 2020 compared to the previous year was found for voivodeships: Greater Poland, Masovia, Silesian, and Subcarpathian (No.: 5, 7, 14, and 16) (Figures 5 and 6).

In 2018, based on confirmed data from the gardening website, C. perspectalis was reported from 57 places. They were located within ten voivodeships (out of 16): Greater Poland, Masovian, Lower Silesian, Łódź, Holy Cross, Lublin, Opole, Silesian, Lesser Poland, and Subcarpatian (No.: 5, 7, 9, 10, 11, 12, 13, 14, 15, and 16). Most information about damaged box trees came from the Silesian and Subcarpathian voivodeships (No.: 14 and 16) (Figure 7). The box tree moth spread in Poland in 2012-2017 from West to East (along with the arch of the Sudetes and the Outer Western Carpathians) - green arrows. It is the main road axis of southern Poland (A4 motorway) from West to East. However, the large number of discovered sites of C. perspectalis in 2016-2017 in the Subcarpathian Region (green oval) may be the result of an invasion of the boxwood moth from South Slovakia where its presence was recorded the first time in Zvolen, Košice, and Presov in 2013 [20,37]. 


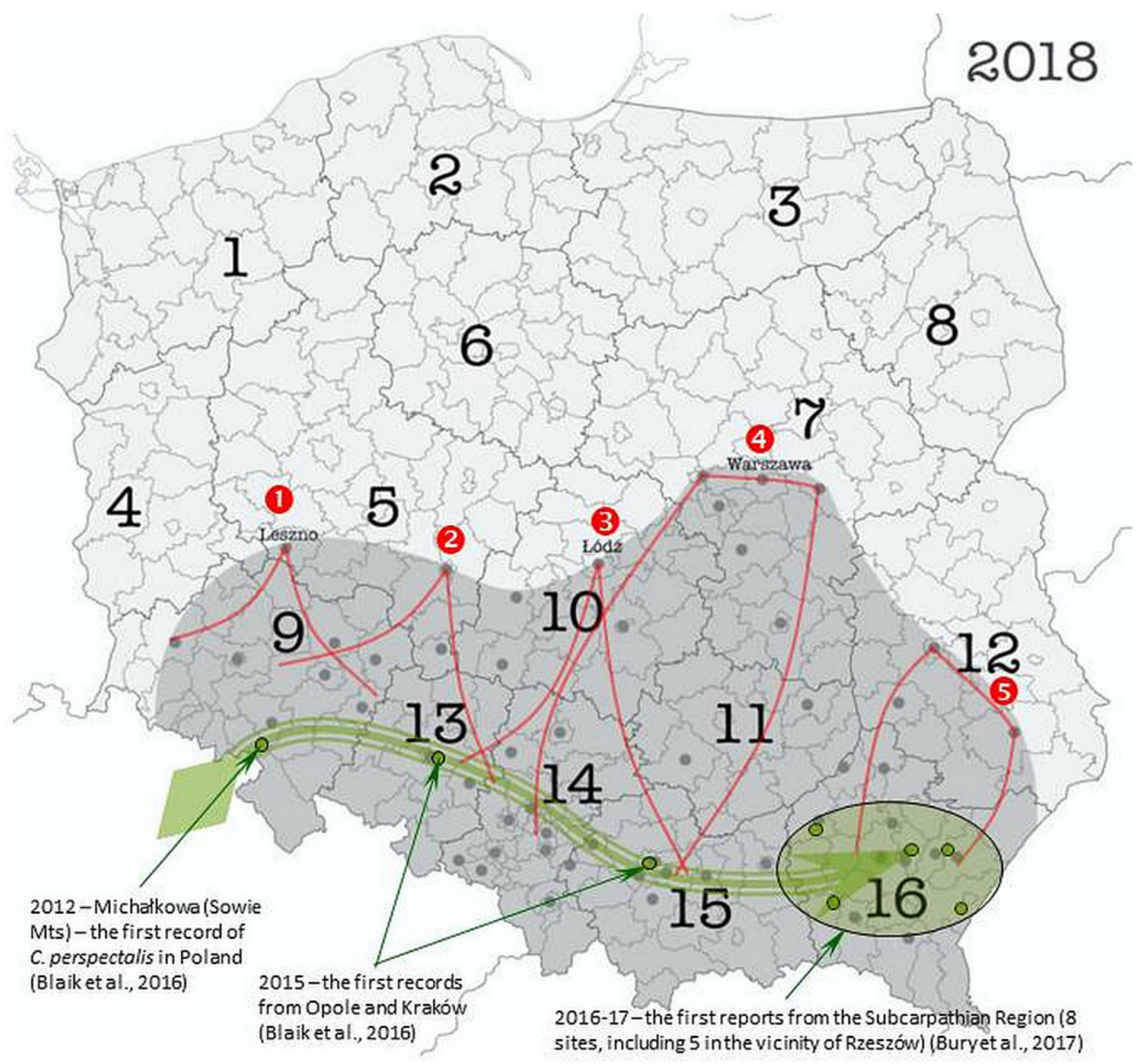

Figure 7. The range of Cydalima perspectalis occurrence in Poland in 2018 and its possible routes of spread. Each grey point indicates the presence of a pest found in social monitoring in 2018; the green arrow marks the route for insects to spread until 2017 [25,26]; red lines and numbers indicate the main directions of the species expansion to the north in 2018; 1-16: numbers assigned to individual voivodships; see Table 1; (1-5: extreme, key locations for the expansion of C. perspectalis in Poland, recorded in 2018 — see the text below.

The northernmost points of the C. perspectalis range recorded in 2018 correspond to the main national and international south-north communication routes. These routes indicate their essential role in the spread of this species to the north of Poland. The most important of them are: the S5 clearway Wrocław-Poznań (Leszno: (0); S11-Opole-Poznań (Kalisz: 2); motorways: latitudinally running A4 from Opole via Katowice to Kraków along with the A1 motorway running north from Katowice to Łódź (3) and further to Warsaw (4) and with the S7 clearway from Kraków to Warsaw (4); S19 from Rzeszów to Lublin with a branch to Zamość (5) (Figure 7).

In 2019, the presence of $C$. perspectalis was found in 77 localities located in 13 voivodeships. These were the same voivodeships as in the previous years. Additionally, the pest appeared in the country's west and the north in the following voivodeships: West Pomeranian, Pomeranian, and Lubusz (No.: 1, 2, and 4). The pest's appearance in Szczecin and Gdańsk, on the coast of the Baltic Sea, was a big surprise. This year, the most information about the species' appearance came from the south of Poland in the following voivodeships: Silesian, Lesser Poland, and Subcarpathian (No.: 14, 15, and 16) (Figure 8). The confirmed presence of C. perspectalis in Polish port cities on the Baltic Sea (Szczecin and Gdańsk) may result both from the movement along communication routes along the Odra and Warta river valleys (Szczecin) and/or from sea transport from Western Europe (or even from Asia)—-the presence of moths in Gdańsk and Szczecin. 


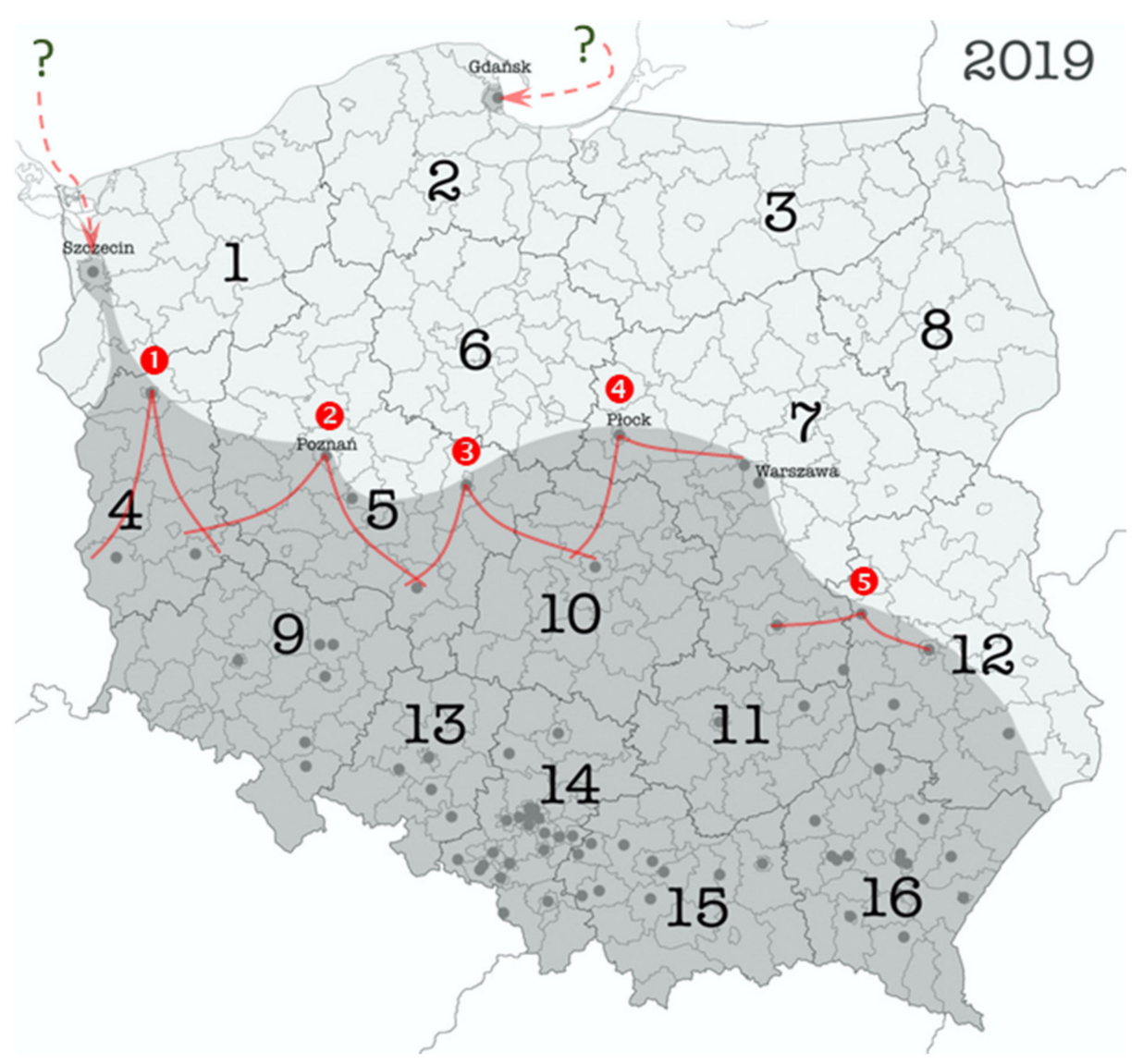

Figure 8. Cydalima perspectalis occurrence range in Poland in 2019 and its other possible routes of spread. Each grey point indicates the presence of a pest found in the course of social monitoring in 2019; red lines and numbers indicate the main directions of the species expansion to the north in 2019; 1-16: numbers assigned to individual voivodships; see Table 1; 1-5: extreme, key locations for the expansion of C. perspectalis in Poland, recorded in 2019—see the text below.

Once again, major communication routes reflect the further spread of $C$. perspectalis to the north. These include: S3 Wrocław/Legnica-Szczecin clearway (report from Gorzów Wielkopolski (1); clearway S5 to Poznań (2); latitudinally running A2 Poznań-Warsaw motorway (report from Konin: 3). On the other hand, road routes of local importance, such as Warsaw-Bydgoszcz or Lublin-Puławy allowed insects to reach Płock (4) and Puławy (5) - places only about $100 \mathrm{~km}$ away from Warsaw or Łódź or $50 \mathrm{~km}$ from Lublin (Figure 8).

In 2020, there was a further large-scale expansion of C. perspectalis in Poland. Information about the pest's outbreak came from as many as 148 localities located in all 16 voivodeships that are part of Poland's administrative division. The last three voivodeships are Warmian-Masurian, Kuyavian-Pomeranian, and Podlaskie (No.: 3, 6, and 8). In addition to Gdańsk and Szczecin, the pest was recorded in such towns in the north of the country as Elblag, Olsztyn, Ełk, Suwałki, and Bielsk Podlaski. The year 2020, however, confirmed earlier observations that currently C. perspectalis is most abundant in southern Poland, where it is warmer than in the north and where the vegetation period is slightly more extended (Figure 9). 


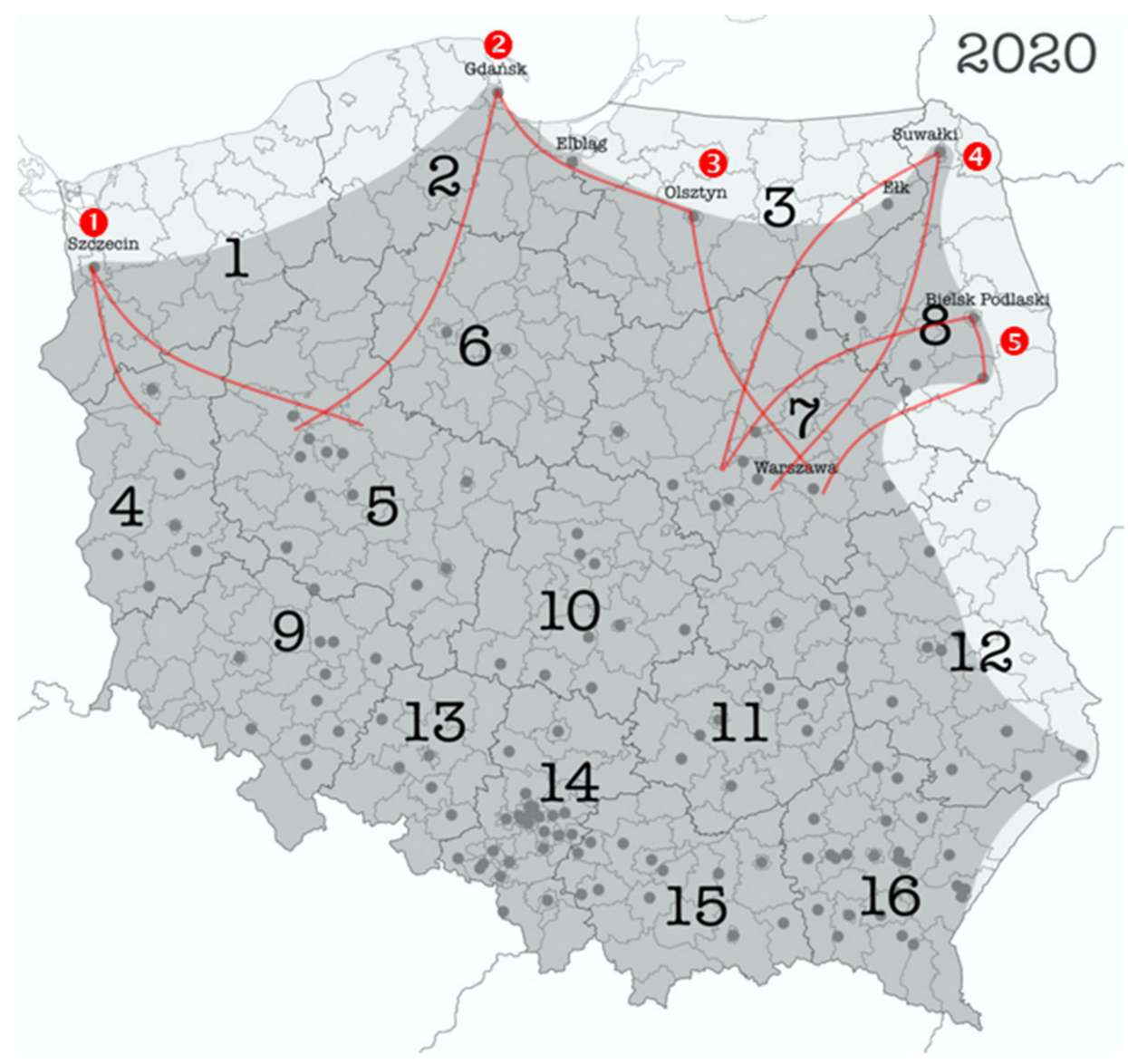

Figure 9. Cydalima perspectalis occurrence range in Poland in 2020, and its final possible routes of spread. Each grey point indicates the presence of a pest found in the course of social monitoring in 2020; red lines and numbers indicate the main directions of the species expansion to the north in 2020; 1-16: numbers assigned to individual voivodships; see Table 1; 1-5: extreme, key locations for the expansion of C. perspectalis in Poland, recorded in 2020-see the text below.

Data from 2020 confirms the role of the main national and international communication routes. The presence of C. perspectalis in Szczecin (0) reflects the route of clearway S3 (from Gorzów Wielkopolski) and S11 (from Poznań). The presence of insects in Gdańsk (2) indicates a significant role of the A1 motorway along the main south-north communication axis and the S7 clearway from Warsaw to Gdańsk via Olsztyn and Elblag (3). The main communication axes from Poland to the northeast to the border with Lithuania (clearway S62) made it easier for insects to reach Suwałki and Ełk (4) and to the border with Belarus (S8) to Bielsk Podlaski (5) (Figure 9).

The number of $C$. perspectalis records reported in 2020 is extremely interesting if the number of inhabitants is considered. Comparing only two voivodeships: Silesian and Subcarpathian (No.: 14 and 16)), where the number of reported records is similar (Figure 7), after such recalculation, the number of records from Silesia is comparable to other voivodeships in southern and western Poland. Despite its small area, the Silesian voivodeship (after the Masovian voivodeship with the capital of Warsaw) has the second largest number of inhabitants. A large number of records from the Subcarpathian voivodeship (No.: 16), with a relatively small number of inhabitants, probably results from the fact that the authors of the monitoring and website come from Rzeszów, where its excellent promotion took place (Figure 10). 


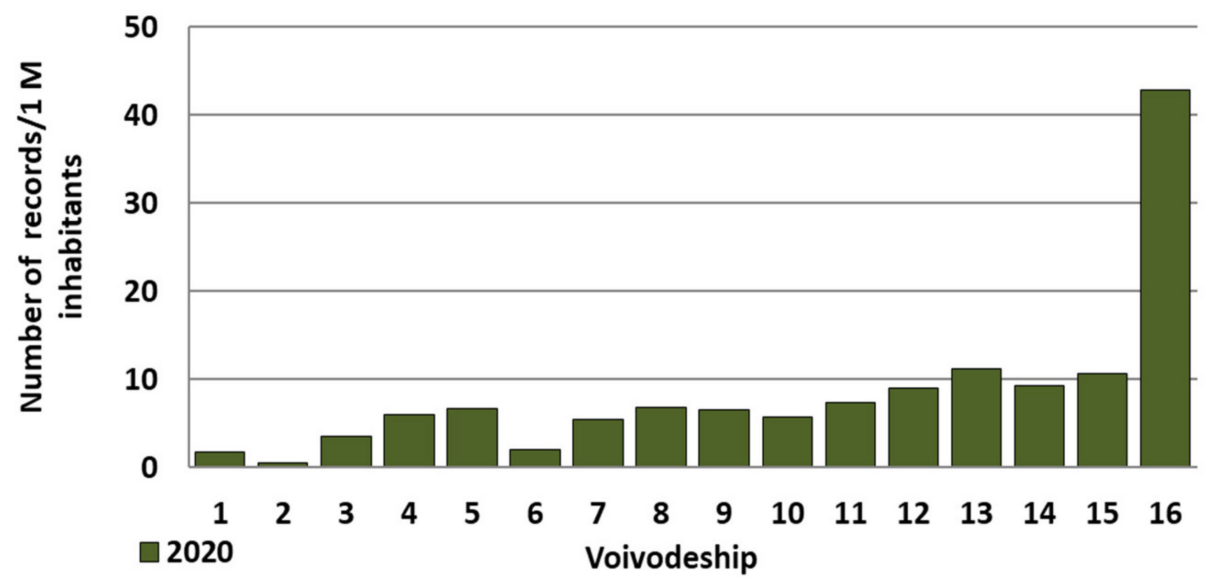

Figure 10. The number of confirmed records of Cydalima perspectalis occurrence in individual voivodeships in 2020 per $1 \mathrm{M}$ inhabitants. Axis X: 1-16-numbers assigned to individual voivodships; see Table 1.

3.2. Ostrinia nubilalis, Diabrotica virgifera virgifera, Cameraria ohridella (Selected Result Issues for Comparative Purposes)

Ostrinia nubilalis. Although the species was recorded for the first time in Poland on millet (Panicum miliaceum) in the 1930s, and then in the 1950s on Zea mays, it became a severe pest of maize cultivation in Poland beginning of the 21st century. Published data show that from the 1950s to the 1990s, this pest was recorded in a limited number only in south-eastern Poland (No.: 15 and 16) and was closely related to the cultivation of maize in areas with optimal conditions for its cultivation. However, in the last two decades, the total area of maize cultivation in Poland has been systematically growing. In 2008, its cultivation area was over 730 thousand hectares, but in 2012 this area increased very quickly to over 1 million hectares [38,39]. Such a rapid increase in the area of maize sown was caused by the freezing of winter cereals and winter rape at the turn of 2011/2012, which prompted farmers to cultivate maize [40]. Since 2012, maize has been sown every year in Poland on more than one million hectares [41]. Data from the Central Statistical Office (CSO) show that maize is sown in all 16 voivodeships. There is, however, regional differentiation of maize sowing in terms of the use of the crop. In the south, grain is dominated, and in the north, silage is dominated [42]. The great interest in maize cultivation resulted in the densification of crops and the reduction of the distance between the cultivation of this plant in all provinces. The above-presented trend in the change of maize cultivation in Poland was favorable for the spread of pests of this crop.

Monitoring carried out in 2004-2008 stated that in the first decade of the 21st century, O. nubilalis began to quickly infect maize cultivation towards the northwest (No.: 1, 4, and 5)-Figure 11. Up to the end of 2008, damaged plants caused by caterpillars were recorded in 185 counties located in 14 voivodeships [31]. From 2009, it could be found in almost the entire country, except for central Poland and the eastern part of Pomerania (No.: 2 and 7). Notably, the expansion of this pest to the north of Poland reflects the increase in maize acreage in the first decade of the 21st century in central and northern Poland. The monitoring carried out in 2010-2012 showed the permanent presence of this species in almost all of Poland [32]-Figure 11. Apart from the increase in the area and the spread of maize cultivation, it is difficult to indicate for $O$. nubilalis a dispersion factor other than a slow, local expansion into subsequent adjacent areas of cultivation with often limited crop protection against pests. 


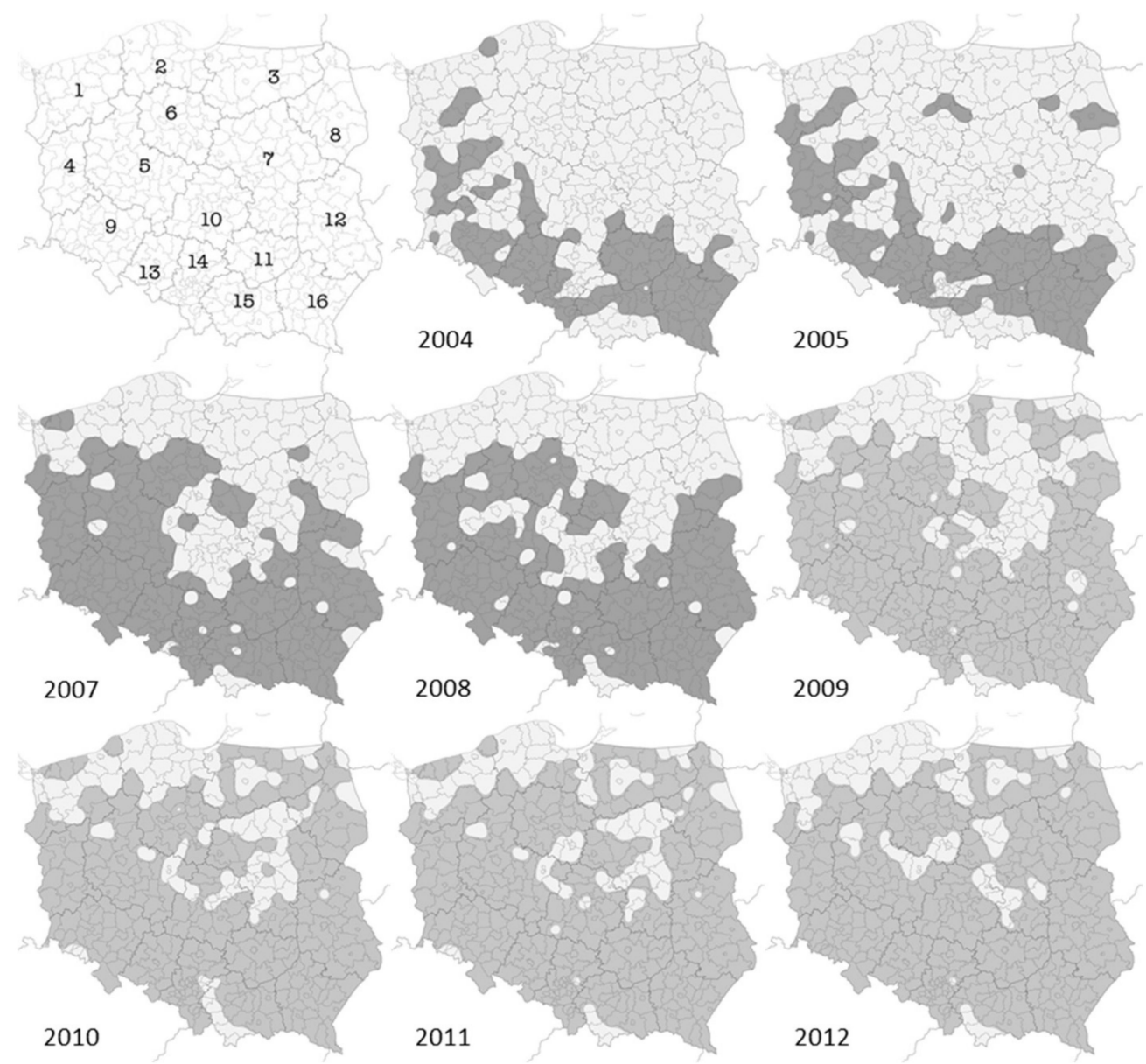

Figure 11. Stages of expansion of Ostrinia nubilalis in Poland (grayed out areas) identified as part of the national monitoring of this species carried out by the State Plant Health and Seed Inspection Service (SPHSIS) and the Institute of Plant Protection-National Research Institute, Regional Experimental Station in Rzeszów (IPP-NRI) in 2004-2012 [31,32]-modified; 1-16: numbers assigned to individual voivodships; see Table 1.

Diabrotica virgifera virgifera in Poland was first recorded in August 2005 in the southeastern part of the country in Subcarpathian voivodeship (No.: 16) in three outbreaks, near Dukla, Łaka, and Jasionka, where six adults were collected [33] -Figure 12. The first recording of this species in Poland is closely related to the transit of freight from Hungary via Slovakia to Poland, the site at the Polish-Slovak border crossing in Dukla, and maize cultivation in the areas adjacent to the airport in Rzeszów (No.: 16). By 2007, D. virgifera had infested entire south-eastern Poland and the border areas with the Czech Republic, including almost the entire Opole Voivodeship (No.: 13, 15, and 16, and partially $9,11,12$, and 14) [34]. Unpublished data from the SPHSIS archive, in which data from the national monitoring of this species in 2008-2013 are stored, clearly indicate a relatively slow but successive infestation of subsequent maize crops in neighboring administrative units (Figure 12). 

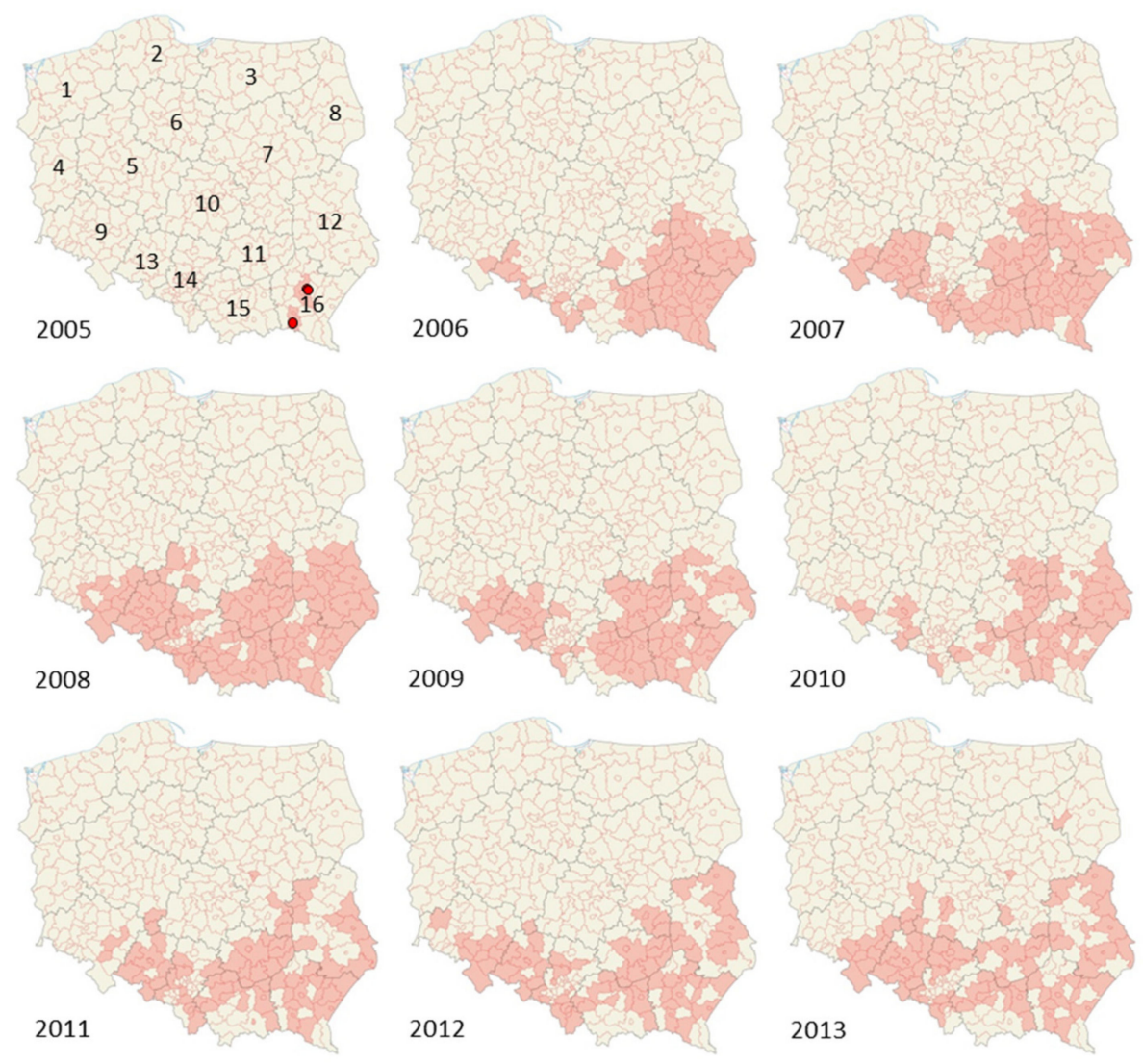

Figure 12. Stages of expansion of Diabrotica virgifera virgifera in Poland identified as part of the national monitoring of this species by the State Plant Health and Seed Inspection Service (SPHSIS) in 2005-2013 [34]-modified and SPHSIS archives. The red points indicate the first described localities of D. virgifera in Poland in 2005 [33]; 1-16: numbers assigned to individual voivodships; see Table 1.

Cameraria ohridella. Horse chestnut-Aesculus hippocastanum is a tree initially found only in park and roadside plantings as an ornamental plant. Currently, it is also found in the wild almost all over Poland (Figure 13a) [43]. The horse chestnut pest, Horse-chestnut leaf miner-C. ohridella, was first recorded in Poland in 1998 in the Botanical Garden in Wojsławice, $50 \mathrm{~km}$ south of Wrocław (No.: 9) near the S8 clearway from the Czech border to Wrocław and on to Warsaw [35]. A year later, a mass appearance of Horse-chestnut leaf miner was found, and trees were heavily damaged in the country's southern regions, in the vicinity of Cieszyn, Pszczyna, and Racibórz (No.: 14). These are towns located in the border zone with the Czech Republic. Therefore, another unintentional introduction from the Czech Republic using the natural south-north migration route, the Moravian Gate and the communication routes running through it from the Czech Republic (A1 motorway and S52 clearway) cannot be ruled out. In 2001, insects of this species were noted in the provinces of southern Poland (No.: 9, 15, and 16) and, also, in central Poland (No.: 5, 7, 10, and 11), reaching Masuria in the north (No. 3). In 2002, the first damage to the chestnut tree was recorded on the German border in Słubice (No.: 4), on the Baltic coast (Kołobrzeg and Sopot-No.: 1 and 2) and in eastern and north-eastern Poland (Lublin and BiałystokNo.: 8 and 12). These data indicate that from the site near Wrocław, where it was found for the first time (and perhaps also from the sites described in 1999 in Silesia-No.: 14), the expansion of insects was two-way-eastwards towards Ukraine and through Central Poland to the north-east towards Belarus, and the west towards the Polish-German border (Słubice) and Pomerania (Figure 13b). The explanation for such a rapid appearance of the Horse-chestnut leaf miner in Warsaw and Masuria is possible, only taking into account the use of road transport and the main south-north communication axes, such as the A1 motorway (Cieszyn-Katowice-Warsaw and further north) and the A4 motorway running 
through Krakow to Rzeszów and the Polish-Ukrainian border. Fifteen years later, the same communication routes were used in their expansion by Cydalima perspectalis (Figures 7-9). In 2002 C. ohridella was already recorded nationwide in many scattered locations, confirmed by the anthropogenic dispersion pattern of this species in Poland, which is estimated on average at least $200 \mathrm{~km}$ per year. Currently, this species inhabits all of Poland, and its range coincides with the distribution of the common horse chestnut in Poland (Figure 13a).

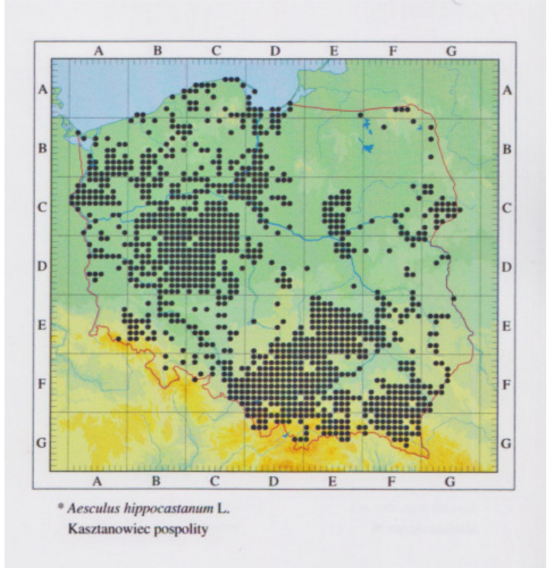

(a)

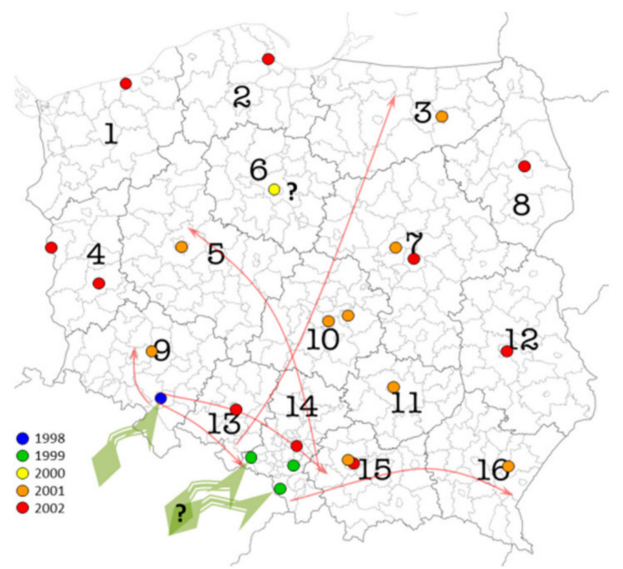

(b)

Figure 13. (a) A map of the distribution of the horse chestnut (Aesculus hippocastanum) in Poland [43]; *: each black point represents confirmed sites of A. hippocastanum in Poland; (b) the first recorded sites of the occurrence of Cameraria ohridella in Poland in the years 1998-2002, the arrows indicate the areas of the main directions of insect spread [35,36]-modified. 1-16: numbers assigned to individual voivodships; see Table 1.

\section{Discussion}

Such a sudden increase of knowledge in the Cydalima perspectalis range, which covered entire Poland for a few years, might be related to the fact that various media started talking about the appearance of the box tree moth due to the information campaign. For this reason, gardeners were more aware of the presence of specimens of a new pest species and were more likely to observe the boxwood plants, including detecting them more often.

Assuming that it usually takes two years from the first appearance of insects to boxwood until they are entirely defoliated, we can assume that the data sent by users of the gardening website are just such a consequence of a two- or three-year delay in detecting the pest $[19,44]$. Information from observers indicates that the natural expansion of this insect in Poland was a secondary factor, an example of which is the 8-year long settlement route in southern Poland in the latitudinal direction along the Carpathian arc. It should be assumed that the main factor was accidental, untargeted transfers of insects with infected plants through the use of road transport and resale of infected plants in subsequent parts of the country. An example is that in 2019 the presence of C. perspectalis was noted in Gdańsk, at a distance of over $300 \mathrm{~km}$ from the previous year, the closest place of the outbreak in Płock (Figures 8 and 9). It cannot be ruled out that C. perspectalis reached the Baltic coast independently by sea transport. It can also be stated that most of the new insect occurrence sites are associated with large cities. The rapid expansion in the last three years was also favored by warmer, above the long-term norms, average daily and monthly temperatures. The hot and long autumn of 2019 was the reason for the third generation of insects' mass appearance.

In Poland, the box tree moth easily survives during the winter period. In spring, as the temperature rises, the over wintering caterpillars start foraging, so the first adults appear at the beginning of April [45]. In Central Europe, the insect develops 2-3 generations a year, depending on weather conditions [17]. In 2018 in south-eastern Poland, due to the dry and hot summer, the 4 th generation of this pest was likely to be developed because 
active moths were found in November [45]. Adults C. perspectalis can fly up to $10 \mathrm{~km}$ per year, then a long-range invasion of the pest (especially in Europe) is favored by bulk freight or boxwood cargo transport. Local dispersion is facilitated by, e.g., hedges, horticulture, nursery gardens, or internet sales [46].

In the last 30 years, over 30 species of insects, alien to the Polish entomofauna, has been found in Poland [28]. However, some of them were particularly spectacular and of real economic importance. These include the invasions of Ostrinia nubilalis (European corn borer), Diabrotica virgifera virgifera (Western corn rootworm), and Cameraria ohridella (Horse-chestnut leaf miner). There are many differences and similarities to that found for C. perspectalis in their pace and spread directions.

For example, in the monitoring studies carried out in the United States on D. virgifera, it was found that adult insects, under favorable conditions, move an average of several dozen kilometers per year (under the most favorable conditions, a natural dispersion of insects over a distance of over $100 \mathrm{~km}$ was recorded). The effect of such a pattern of spreading the Western corn rootworm was the appearance of insects only in the areas adjacent to the previously infected $[47,48]$. In Poland, for D. virgifera, spreading over much smaller distances was observed, up to several dozen kilometers per year. However, spreading was favored by lowland terrain and the fragmentation of field crops of maize, which, with the doubling of maize crops in 2005-2013, caused a progressive invasion of D. virgifera to the north and north-east. The only exception was the presence of D. virgifera in 2013 in Podlaskie voivodeship (No.: 8), which was undoubtedly brought to this area using transport or plant material. Studies on the spread of D. virgifera in Europe in countries such as Italy, France, Germany, Austria, and Switzerland have confirmed that the rapid spread of the species is related to the total acreage of maize cultivation in a given area. Areas that cover more than $50 \%$ of the acreage are classified as "high-risk areas" for this species' invasions [49]. These data fully corresponded to the $D$. virgifera dispersion pattern in Poland, which confirm the rapid invasion of the species in traditional maize cultivation areas (south-eastern Poland) and the increase in the range of occurrence with the increase in the acreage after 2008. A similar pattern of insects spread from pest-infested areas to nearby pest-free areas was observed for $O$. nubilalis. An additional factor contributing to the spread of this species was the abrupt increase in the acreage of maize cultivation in 2012 [41].

A completely different spreading strategy was observed for the third mentioned above invasive pest. The high rate of spread of $C$. ohridella and the rapid increase in its occurrence range is mainly attributed to road transport. In many cases, the favorable factors were tree stands located near the main communication routes, from which people, animals, or wind further transmitted insects to other trees. It is estimated that the distribution range of Horse-chestnut leaf miners increased in Europe at a rate of about $60 \mathrm{~km}$ to $114 \mathrm{~km}$ per year [50].

With large-scale spatial data of the occurrence of a given invasive species, several spatial models of the spread of insects to new, uninfected areas can be distinguished. These include, among other things, a diffusion model, a leptokurtic dispersal model and a stratified dispersal model [50,51]. Comparing the pace and directions of the insect's habitat mentioned above species in new areas of Poland, it should be stated that two basic ways of infesting new areas can be distinguished. The first is related to pests of arable crops, good examples of which are $O$. nubilalis and $D$. virgifera. These insects, closely related to crops, in this case, maize, take over successive areas gradually, usually over short distances (about $50 \mathrm{~km}$ in the direction of neighboring crops). An important factor contributing to the dispersion is the high density of the host plant crops and the short distance between them. On the other hand, the slowing down of the dispersion rate is associated with plant protection treatments and the applicable phytosanitary regulations. A diffusion model can best describe the spread of $O$. nubilalis and D. virgifera $[50,51]$.

On the other hand, species of no economic importance, such as, for example, $C$. ohridella, take over new areas in a jump-like manner, sometimes over long distances, often 
hundreds of kilometers, using land transport means (including water and air transport). Five years was enough for this species to be recorded throughout Poland, both on trees growing in areas not cared for by humans and those of a decorative and recreational nature. In the analyzes of the models of the spread of this species in Germany and France, it was found that this process is best described by a leptokurtic dispersal and a stratified dispersal model. It was also found that a stratified dispersal model incorporating the effect of human population density provides the best description of the spread of $C$. ohridella in many countries of Europe [50,51].

The use of social networks and dedicated websites dedicated to societies and interest groups' activities is not the first time this type of approach has been used to research the distribution of insects. C. perspectalis meets most of the insect criteria suitable for this type of social monitoring. It is a species that feeds close to humans, causes specific and massive boxwood dieback symptoms, visible to everyone, even to people who are not interested in entomology. It is only necessary to consider the time insects need from the first colonization of plants to their death-about two years [19]. The lack of natural enemies enables a more precise determination of the year of insects' appearance in a given area. Previously, this type of approach was used in the British Isles where, in addition to the official operating The British and Irish network of County Moth Recorders (CMRs), which was the primary source of fully reliable records of the species, the website of the European Boxwood and Topiary Society (EBTS) provides a facility for users to report occurrences of this species and we have accessed all such data for 2018 (www.ebts.org/bmctracker) (accessed on 22 February 2021) [11]. A similar approach that reflects Citizen Science's idea has been successfully used in recent years in Toronto (Canada), where the first appearance of $C$. perspectalis was recorded in August 2018 [52].

Observations made by Blaik et al. [25] and Bury et al. [26] were used by EPPO to map the distribution of $C$. perspectalis in Europe [53]. In turn, the map of $C$. perspectalis distribution in Europe conducted by CABI lacks detailed information on the occurrence of the species in Poland, including its first appearance [54].

Genetic studies based on mtDNA for cytochrome oxidase genes revealed two haplotypesHTA and HTB - in Europe out of twelve identified in Chinese populations of C. perspectalis. These results support the hypothesis of multiple introductions of this pest from eastern China to Europe. Lack of precise trade regulations for ornamental plants and trade globalization facilitated the rapid spread of the pest [4,7]. The lack of genetic research data on the population in Poland does not allow for an unambiguous statement whether the spread of $C$. perspectalis is the result of a single introduction to the southwest of Poland from the Czech Republic or it is multiple introductions (from the Czech Republic, Slovakia, and Germany, or through the Baltic ports from Denmark or Sweden). Research of this type could provide an answer about the origin of this species in the cities of northern voivodeships (Szczecin, GdańskFigure 8). It cannot be ruled out that these cities may have been infested with insects from Denmark or Sweden, where this species was first recorded in 2013 and 2016 [54].

Due to the lack of nationwide monitoring of the box tree moth's occurrence in Poland, data on the presence of the pest came only from random observations. Without the involvement of state services dealing with the monitoring of alien origin species, it was impossible to create an accurate map of the range of this species in Poland. Our observations in 2018-2020 clearly show the growing range of $C$. perspectalis in Poland. The obtained data indicate that the main directions of the species spread in Poland were the main communication axes of the country. A good example to justify such a thesis is the sudden appearance of several confirmed positions in the Subcarpathian Voivodeship (No.: 16) in 2016-2017. Data on the spread of this insect in Hungary and Slovakia confirm its presence in large Hungarian cities as early as 2011, and the following year it will appear in Slovakia. In 2013 and 2014, the insect was recorded in Prešov (a large communication junction in eastern Slovakia) and Košice. These localities lie on the main communication axis from Slovakia to Poland (Košice-Prešov-Rzeszów) [37,55]. On the other hand, the detected presence of C. perspectalis in Lithuania in 2018 in Vilnius is unrelated to the spread of insects 
along the axis of transit transport from southern Europe to the Baltic countries running through Poland [56]. C. perspectalis was recorded in the north-eastern voivodships bordering Lithuania only in 2020 in towns lying on the extension of the Warsaw-Ełk/Suwałki-Vilnius clearway. This assumption strengthens the thesis that the box three moth reaches new areas of Europe by sea transport, which may explain the earlier appearance of this species in large port towns (Szczecin, Gdańsk, Poland) in Poland as early as 2019 (Figure 8).

For C. perspectalis, an invasive pest of boxwood, a plant that grows in Poland only due to artificial plantings, a similar spreading pattern can be observed as in C. ohridella. It has been proven that the spread of this species is related to the use of land transport and the density of the human population - a stratified dispersal model. This model best explains the unintentional long-distance movement of the pest within one growing season, which may have resulted from the long-distance trade of infected plants. At the same time, an essential factor influencing the rate of spread of a species is the density of the human population, favoring local spread over short distances, locally matching the diffusion model [50,51]. Such a dispersion model is well reflected in the published maps for Switzerland, Hungary, and Slovakia, where the first recorded sites of this species begin with large cities and then along the main communication routes between them $[7,11,37,55,57]$. The time it took for C. perspectalis to infect all of Poland was only twice as long as that stated for C. ohridella. The years 2018-2020, in which citizen monitoring of the occurrence of the box tree moth was carried out, were crucial to the invasion of the whole of Poland.

Proposed by Nacombo et al. [5], a bioclimatic $\left(\right.$ CLIMEX $\left.{ }^{\circledR}\right)$ model for C. perspectalis distribution in Europe, based on climate, ecological, and developmental parameters described for this species (e.g., diapause termination, thermal requirements and phenology) well reflects the directions of expansion of this pest in Poland. The places of occurrence of the box tree moth confirmed in 2020, as well as the number of raised records, correctly reflect the predictions obtained using the bioclimatic model (compare with Figure 9), pointing to the regions of south-eastern (No: 12,14, and 16), central (No.: 5 and 10), and western (No.: 4) Poland. Similar analyses performed for the Slovak population confirm the model's usefulness [5,55]. Perhaps the model used should have been enriched, as was conducted for C. ohridella, with the human population density parameter, as it was conducted in the model to predict this invasive species for horse chestnut in a stratified dispersal model $[5,50,51,55]$.

However, it should be noted that most of the obtained data were provided by gardeners and plant breeders, who often did not know about the appearance in Poland in the area where a new, alien species of pest lived. Some gardeners, boxwood growers, and institutions dealing with urban greenery and parks lost their boxwood bushes, topiaries, and hedges, which caterpillars utterly destroyed. Such a rapid and spectacular invasion of $C$. perspectalis in Poland makes it necessary to research to understand the biology of this species under Polish conditions. In this, it is essential to develop comprehensive methods of its control using biological and chemical methods, which will take into account Poland's climatic and weather conditions and the methods of growing boxwood [40,58,59].

\section{Conclusions}

The collected data indicate that the box tree moth (Cydalima perspectalis) took over its entire area from its first discovery in 2012 in Poland in 2020. Insects have spread throughout the country, often over long distances, using major communication routes. Currently, it is the greatest threat to boxwood in southern and central Poland. The lack of nationwide monitoring of $C$. perspectalis makes it challenging to control its spread and combat it, especially in regions where it appears the first time. The developed coverage maps, together with the data on recording the presence of $C$. perspectalis, allow gardeners and plant breeders to analyze the situation on an ongoing basis and undertake adequate control and eradication methods. 


\begin{abstract}
Supplementary Materials: The following supporting information can be downloaded at: https: / / www.mdpi.com/article/10.3390/d14010022/s1: Table S1: The number of places where the appearance of Cydalima perspectalis was recorded and the number of reports of insects in individual voivodeships, in 2018-2020; Table S2: Detailed list of places (towns) in which the occurrence of Cydalima perspectalis was recorded and confirmed in 2018-2020.
\end{abstract}

Author Contributions: P.K.B. and M.N. conceived and designed the experiments; Ł.K., M.G. and P.K.B. performed the experiments; M.A., M.N. and P.K.B. analyzed the data; M.N., P.K.B. and P.Z. wrote the paper. All authors have read and agreed to the published version of the manuscript.

Funding: This research received no external funding.

Institutional Review Board Statement: Not applicable.

Informed Consent Statement: Not applicable.

Data Availability Statement: All data used in the publication are available at the WWW addresses of the links quoted. If there are no citation, the data used are not in any public database. Raw data on the presence of C. perspectalis, O. nubilalis and D. virgifera in Poland are available only in internal reports of the Institute of Plant Protection.

Acknowledgments: The authors would like to thank all the gardeners cooperating with the gardening site "Allotment and Garden Our Passion (DIONP)" for the data provided on the range of C. perspectalis occurrence in Poland in 2018-2020. We want to express special thanks to the owner of this gardening website, Beata Bereś. We also thank Tomasz Konefał from the Main Inspectorate of Plant Health and Seed Inspection in Torun for his help in the graphic development of maps of C. perspectalis occurrence range in Poland.

Conflicts of Interest: The authors declare no conflict of interest.

\title{
References
}

1. EPPO Global Database: Reporting Service No. 11-2007. Num. Article: 2007/215 Incursion of Diaphania perspectalis in Germany and Addition to the EPPO Alert List. Available online: https://gd.eppo.int/reporting/article-1295 (accessed on 3 December 2020).

2. Mally, R.; Nuss, M. Phylogeny and nomenclature of the box tree moth, Cydalima perspectalis (Walker, 1859) comb. n., which was recently introduced into Europe (Lepidoptera: Pyraloidea: Crambidae: Spilomelinae). Eur. J. Entomol. 2010, 107, 393-400. [CrossRef]

3. Wan, H.; Haye, T.; Kenis, M.; Nacambo, S.; Xu, H.; Zhang, F.; Li, H. Biology and natural enemies of Cydalima perspectalis in Asia: Is there biological control potential in Europe? J. Appl. Entomol. 2014, 138, 715-722. [CrossRef]

4. Bras, A.; Avtzi, D.N.; Kenis, M.; Li, H.; Vétek, G.; Bernard, A.; Courtin, C.; Rousselet, J.; Roques, A.; Auger-Rozenberg, M.-A. A complex invasion story underlies the fast spread of the invasive box tree moth (Cydalima perspectalis) across Europe. J. Pest Sci. 2019, 92, 1187-1202. [CrossRef]

5. Nacambo, S.; Leuthardt, F.L.G.; Wan, H.; Li, H.; Haye, T.; Baur, B.; Weiss, R.M.; Kenis, M. Development characteristics of the box-tree moth Cydalima perspectalis and its potential distribution in Europe. J. Appl. Entomol. 2014, 138, 14-26. [CrossRef]

6. Strachinis, I.; Kazilas, C.; Karamaouna, F.; Papanikolaou, N.E.; Partsinevelos, G.K.; Milonas, P.G. First record of Cydalima perspectalis (Walker, 1859) (Lepidoptera: Crambidae) in Greece. Hell. Plant Prot. J. 2015, 8, 66-72. [CrossRef]

7. Matošević, D.; Lukić, I.; Bras, A.; Lacković, N.; Pernek, M. Spatial distribution, genetic diversity and food choice of box tree moth (Cydalima perspectalis) in Croatia. South-East Eur. Forest. 2017, 8, 41-46. [CrossRef]

8. Nagy, A.; Szarukán, I.; Csabai, J.; Molnár, A.; Molnár, B.P.; Kárpáti, Z.; Szanyi, S.; Tóth, M. Distribution of the box tree moth (Cydalima perspectalis Walker 1859) in the north-eastern part of the Carpathian Basin with a new Ukrainian record and Hungarian data. EPPO Bull. 2017, 47, 279-282. [CrossRef]

9. Gómez-Undiano, I.; Martínez-Ovejero, P.; Villegas, S.; Prieto, N.; Herrero, A.; Moreno, A.V. First record of Cydalima perspectalis (Walker, 1859) for Madrid, Spain (Lepidoptera: Crambidae, Spilomelinae). SHILAP-Rev. Lepidopt. 2018, 46, 585-591.

10. EPPO Global Database: Reporting Service No. 06-2019. Num. Article: 2019/118, Update on the Situation of Cydalima perspectalis in the EPPO Region. Available online: https:/ /gd.eppo.int/reporting/article-65482019 (accessed on 3 December 2020).

11. Plant, C.W.; Poole, C.; Salisbury, A.; Bird, S. The box-tree moth Cydalima perpectalis (Walker, 1859) in Britain: An overview of its spread and current status. Entomol. Rec. J. Var. 2019, 131, 122-147.

12. CABI-Invasive Species Compendium, Cydalima perspectalis (Box Tree Moth). Available online: https://www.cabi.org/ISC/ datasheet/118433 (accessed on 3 December 2020).

13. Vieira, V. First record of Cydalima perspectalis (Walker, 1859) from São Miguel Island, Azores (Portugal) (Lepidoptera: Crambidae). SHILAP-Rev. Lepidopt. 2020, 48, 141-146. 
14. Hizal, E. Two invasive alien insect species, Leptoglossus occidentals (Heteroptera: Coreidae) and Cydalima perspectalis (Lepidoptera: Crambidae), and their distribution and host plants in Istanbul province, Turkey. Fla. Entomol. 2012, 95, 344-349. [CrossRef]

15. Hizal, E.; Kose, M.; Yesil, C.; Kaynar, D. The new pest Cydalima perspectalis (Walker, 1859) (Lepidoptera: Crambidae) in Turkey. J. Anim. Vet. Adv. 2012, 11, 400-403. [CrossRef]

16. Poltavsky, A.N.; Ilyina, E.V. New finds of alien Lepidoptera species in Dagestan. Russ. J. Biol. Invasions 2017, 8, 347-350. [CrossRef]

17. Leuthardt, F.L.G.; Baur, B. Oviposition preference and larval development of the invasive moth Cydalima perspectalis on five European box-tree varieties. J. Appl. Entomol. 2013, 137, 437-444. [CrossRef]

18. López, C.; Eizaguirre, M. Diapause and biological cycle of Cydalima perspectalis (Walker) in the eastern Pyrenees. J. Appl. Entomol. 2019, 143, 1096-1104. [CrossRef]

19. Korycinska, A.; Eyre, D. Box Tree Caterpillar Cydalima perspectalis; External Factsheets; The Food and Environment Research Agency (FERA): York, UK, 2009; p. 4, (Updated 2011). Available online: https://webarchive.nationalarchives.gov.uk/20 100713154951/http:/ / fera.defra.gov.uk/plants/plantHealth/pestsDiseases/documents/boxTreeCaterpillar.pdf (accessed on 22 February 2021).

20. Kulfan, J.; Dzurenko, M.; Parák, M.; Sarvašová, L.; Saniga, M.; Brown, P.; Zach, P. Larval feeding of Cydalima perspectalis on box trees with a focus on the spatial and temporal distribution. Plant. Prot. Sci. 2020, 56, 197-205. [CrossRef]

21. Suppo, C.; Bras, A.; Robinet, C.A. Temperature- and photoperiod-driven model reveals complex temporal population dynamics of the invasive box tree moth in Europe. Ecol. Modelling 2020, 432, 109229. [CrossRef]

22. Poitou, L.; Bras, A.; Pineau, P.; Lorme, P.; Roques, A.; Rousselet, J.; Auger-Rozenberg, M.-A.; Laparie, M. Diapause regulation in newly invaded environments: Termination timing allows matching novel climatic constraints in the box tree moth, Cydalima perspectalis (Lep.: Crambidae). Insects 2020, 11, 629. [CrossRef]

23. Canelles, T.Q.; Bassols, E.; Vayreda, J.; Brotons, L. Predicting the potential distribution and forest impact of the invasive species Cydalima perspectalis in Europe. Ecol. Evol. 2021, 11, 5713-5727. [CrossRef]

24. Kenis, M.; Nacambo, S.; Leuthardt, L.G.F.; Di Domenico, F.; Haye, T. The box tree moth, Cydalima perspectalis, in Europe: Horticultural pest or environmental disaster? Aliens: Invasive Species Bull. 2013, 33, 38-41.

25. Blaik, T.; Hebda, G.; Masłowski, J. Cydalima perspectalis (Walker, 1859)—Inwazyjny gatunek motyla w faunie Polski (Lepidoptera: Crambidae). (Cydalima perspectalis (Walker, 1859)—An invasive butterfly species in the fauna of Poland (Lepidoptera: Crambidae). Przyr. Sudetów 2016, 19, 121-124.

26. Bury, J.; Olbrycht, T.; Mazur, K.; Babula, P.; Czudec, P. First records of the invasive box tree moth Cydalima perspectalis (Walker, 1859) (Lepidoptera: Crambidae) in south-eastern Poland. Fragm. Faun. 2017, 60, 101-106. [CrossRef]

27. D'Ornano, M.; Goddyn, S.; Jalkh, J.-F.; Ferrand, E. Motion for a European Parliament Resolution on the Box Tree Moth (Cydalima perspectalis). European Parliament B8-1209/2016. Available online: https://www.europarl.europa.eu/doceo/document/B-8-20 16-1209_EN.pdf (accessed on 22 February 2021).

28. Soika, G.; Łabanowski, G. Organizmy Inwazyjne Wykrywane w Polskich Szkótkach Instrukcja Rozpoznawania Roztoczy i Owadów Inwazyjnych na Podstawie Wygladu i Cech Diagnostycznych (Invasive Organisms Detected in Polish Nurseries. Instructions for Recognizing Mites and Invasive Insects on the Basis of Appearance and Diagnostic Features); Instytut Ogrodnictwa (The National Institute of Horticultural Research): Skierniewice, Poland, 2014.

29. BioMap. Biodiversity Map Taxa: Cydalima perspectalis (F. Walker, 1859). Available online: https://baza.biomap.pl/en/taxon/ species-cydalima_perspectalis/default/tr/y/cf/y (accessed on 22 February 2021).

30. DIONP_Działka i Ogród Naszą Pasją (DIONP-Allotment and Garden Our Passion). Available online: https://www.dionp.pl (accessed on 22 February 2021).

31. Bereś, P.K.; Konefał, T. Distribution range of the european corn borer (Ostrinia nubilalis hbn.) on maize in 2004-2008 in Poland. J. Plant Prot. Res. 2010, 50, 326-334. [CrossRef]

32. Bereś, P.K.; Konefał, T. Występowanie Ostrinia nubilalis (Hbn.) na kukurydzy (Zea mays L.) w Polsce w latach $2009-2012$. (Occurrence of Ostrinia nubilalis (Hbn.) on maize (Zea mays L.) in Poland in 2009-2012). Prog. Plant Prot. 2015, 3, $296-304$.

33. Sahajdak, A.; Bereś, P.K.; Konefał, T. Diabrotica virgifera Le Conte-A new threat to maize crops in Poland and measures taken against the pest. J. Plant Prot. Res. 2006, 46, 157-161.

34. Konefał, T.; Bereś, P.K. Diabrotica virgifera Le Conte in Poland in 2005-2007 and regulations in the control of the pest in 2008. J. Plant Prot. Res. 2008, 49, 129-134. [CrossRef]

35. Łabanowski, G.; Soika, G. Cameraria ohridella damages horse chestnut trees in Poland. Ochr. Roślin 1998, 42, 12-16.

36. BioMap. Biodiversity Map Taxa: Cameraria ohridella Deshka et Dimić. 1986. Available online: https://baza.biomap.pl/pl/taxon/ species-cameraria_ohridella/default/tlpl/y (accessed on 9 November 2021).

37. Vétek, G.; Zach, P.; Matošević, D.; Tuba, K.; Lakatos, F.; Kulfan, J.; Csóka, G.; Gomboc, S.; Nagy, S.; Glavendekić, M.; et al. Invasion by the box tree moth, Cydalima perspectalis (Lepidoptera: Crambidae), in southeastern Europe. In Invasive Dendrophilous Organisms: Challenges and Protection Operations; All-Russian Research Institute of Silviculture and Mechanization of Forestry East Palearctic Regional Section International Organization for the Biological Control of Pests and Animals: Pushkino, Russia, 2019; pp. 17-28.

38. Użytkowanie Gruntów, Powierzchnia Zasiewów i Pogłowie Zwierzat Gospodarskich w 2008 r. (Land Use, Sown Area and Livestock Population in 2008); Central Statistical Office (CSO): Warsaw, Poland, 2008. Available online: www.stat.gov.pl (accessed on 4 November 2021). 
39. Crop Production in 2012; Central Statistical Office (CSO): Warsaw, Poland, 2012. Available online: www.stat.gov.pl (accessed on 4 November 2021).

40. Syp, A. Projekcja zmian wielkości plonów kukurydzy w Polsce i w Unii Europejskiej w 2030 roku (Projected changes in grain maize yields in Poland and European Union in 2030). Stow. Ekon. Rol. I Agrobiz. (Pol. Assoc. Agric. Agribus. Econ.)-Rocz. Nauk. 2015, 17, 373-378.

41. Crop Production in 2017; Central Statistical Office (CSO): Warsaw, Poland, 2018. Available online: www.stat.gov.pl (accessed on 4 November 2021).

42. Księżak, J. Regionalne zrónicowanie uprawy kukurydzy w Polsce w latach 2000-2006 (Regional diversification of maize cultivation in Poland in 2000-2006). Acta Sci. Pol. Agric. 2008, 7, 47-60.

43. Zając, A.; Zając, M. (Eds.) Atlas Rozmieszczenia Roślin Naczyniowych w Polsce: Dodatek (Distrubution Atlas of Vascular Plants in Poland: Appendix); Instytut Botaniki Uniwersytetu Jagiellońskiego (Institute of Botany of the Jagiellonian University): Kraków, Poland, 2019; pp. 25, 182-183.

44. Raineri, V.; Bonechi, F.; Caracciolo, D.; Cresta, P.; Mariotti, M. Cydalima perspectalis (Walker, 1859) (Lepidoptera, Crambidae) and the threats for the Nature 2000 habitat 5110 in Liguria (NW-Italy). Boll. Mus. Ist. Biol. Univ. Genova. 2017, 79, 215-236.

45. Bereś, P. Ćma Bukszpanowa. Azjatycki Najeźdzca Niszczy Bukszpany w Polsce. (Box Tree Moth. An Asian Invader Destroys Box Trees in Poland); Wiedza i Praktyka Sp. z o.o.: Warszawa, Poland, 2019; pp. 1-11.

46. Leuthardt, F.L.G.; Glauser, G.; Baur, B. Composition of alkaloids in different box tree varieties and their uptake by the box tree moth Cydalima perspectalis. Chemoecology 2013, 23, 203-212. [CrossRef]

47. Spencer, J.L.; Hibbard, B.E.; Moeser, J.; Onstad, D.W. Recent research on the western corn rootworm. Behaviour and ecology of the western corn rootworm (Diabrotica virgifera virgifera LeConte). Agric. For. Entomol. 2009, 11, 9-27. [CrossRef]

48. Meinke, L.J.; Sappington, T.W.; Onstad, D.W.; Guillemaud, T.; Miller, N.J.; Komáromi, J.; Levay, N.; Furlan, L.; Kiss, J.; Toth, F. Recent research on the western corn rootworm. Western corn rootworm (Diabrotica virgifera virgifera LeConte) population dynamics. Agric. For. Entomol. 2009, 11, 29-46. [CrossRef]

49. Baufeld, P.; Enzian, S. Maize growing, maize high-risk areas and potential yield losses due to Western corn rootworm (Diabrotica virgifera virgifera) damage in selected European countries. In Western Corn Rotworm-Ecology and Management; Vidal, S., Kuhlmann, U., Edwards, C.R., Eds.; CABI Publishing: Walingford, CT, USA; Cambridge, UK, 2005; pp. 285-302.

50. Gilbert, M.; Grégoire, J.C.; Freise, J.F.; Heitland, W. Long-distance dispersal and human population density allow the prediction of invasive patterns in the horse chestnut leafminer Cameraria ohridella. J. Anim. Ecol. 2004, 73, 459-468. [CrossRef]

51. Gilbert, M.; Guichard, S.; Freise, J.; Grégoire, J.C.; Heitland, W.; Straw, N.; Tilbury, C.; Augustin, S. Forecasting Cameraria ohridella invasion dynamics in recently invaded countries: From validation to prediction. J. Appl. Ecol. 2005, 42, 805-813. [CrossRef]

52. Guarrasi, M.A. Potential Impacts and Control of the Non Native Box Tree Moth in Canada. Frans Eggermont. 2018. Available online: https:/ /www.cif-ifc.org/wp-content/uploads/2019/10/2019ConfPres_S05P2_Potential-Impacts-and-Managementof-the-Non-Native-Box-Tree-Moth-in-Canada-_Mariaelana-A-Guarrasi.pdf (accessed on 3 December 2020).

53. EPPO Global Database: Cydalima perspectalis (DPHNPE). Available online: https://gd.eppo.int/taxon/DPHNPE (accessed on 22 February 2021).

54. Bengtsson, B.Å. Anmärkningsvärda fynd av småfjärilar (Microlepidoptera) i Sverige 2016. (Remarkable records of Microlepidoptera in Sweden during 2016). Entomol. Tidskr. 2017, 138, 1-24.

55. Kulfan, J.; Zach, P.; Holec, J.; Brown, P.M.J.; Sarvašová, L.; Skuhrovec, J.; Martinková, Z.; Honěk, A.; Vál'ka, J.; Holecová, M.; et al. The invasive Box tree moth five years after introduction in Slovakia: Damage risk to Box trees in urban habitats. Forests 2020, 11, 999. [CrossRef]

56. Paulavičiūtè, B.; Mikalauskas, D. First record of the box tree moth Cydalima perspectalis (Walker, 1859) (Lepidoptera: Crambidae) in Lithuania. Liet. Entomol. Draugijos Darb. 2018, 2, 55-59.

57. Leuthardt, F.L.G.; Billen, W.; Baur, B. Ausbreitung des Buchsbaumzünslers Diaphania perspectalis (Lepidoptera, Pyralidae) in der Region Basel-EIne für die Schweiz neue Schädlingsart (Spread of the Box-tree pyralid Diaphania perspectalis (Lepidoptera: Pyralidae) in the region of Basel-A pest species new for Switzerland. Entomo Helv. 2010, 3, 51-57.

58. Bereś, P.K.; Siekaniec, Ł.; Kontowski, Ł.; Kucharska-Świerszcz, M. Przydatność Bacillus thuringiensis, Beauveria bassiana oraz spinosadu w biologicznej ochronie bukszpanu pospolitego przed ćmą bukszpanową w południowo-wschodniej Polsce (Usefulness of Bacillus thuringiensis, Beauveria bassiana and spinosad in the biological control of Cydalimia perspectalis on boxwood in southeastern Poland). In Proceedings of the 60th Scientific Session, Institute of Plant Protection-National Research Institute, Poznań, Poland, 11-13 February 2020; pp. 178-179.

59. Bereś, P.K.; Zawada, D.; Siekaniec, Ł. Efekty chemicznego zwalczania gąsienic ćmy bukszpanowej na bukszpanie pospolitym z wykorzystaniem acetamiprydu oraz mieszaniny acetamiprydu z lambda-cyhalotryna (Effects of chemical control of Cydalima perspectalis on Buxus sempervirens using acetamiprid and mixture of acetamiprid with lambda-cyhalothrin). In Proceedings of the 60th Scientific Session, Institute of Plant Protection-National Research Institute, Poznań, Poland, 11-13 February 2020 ; p. 169. 